\title{
Water Treatment Technology Using Carbonaceous Materials Produced from Vegetable Biomass
}

\author{
Naohito Kawasaki*, Ryoma Bun-ei, Fumihiko Ogata, Takeo Nakamura, \\ Shigeharu Tanei and Seiki Tanada
}

\begin{abstract}
School of Pharmaceutical Sciences, Kinki University, Kowakae, Higashi-Osaka, Osaka 577-8502, Japan

kawasaki@phar.kindai.ac.jp

Running Head: Water Treatment Technology by Vegetable Biomass
\end{abstract}

Corresponding author: Naohito Kawasaki, $\mathrm{Ph}$. D.

School of Pharmacy, Kinki University, Kowakae, Higashi-Osaka, Osaka 577-8502, Japan

TEL: +81-6-6730-5880 ext. 3867 FAX: +81-6-6730-1394 e-mail: kawasaki@phar.kindai.ac.jp

\begin{abstract}
This study investigated the adsorptive capacity for lead ions of wheat bran (WB), which is a vegetable biomass. The results show that in adsorption by $\mathrm{WB}$, lead ions are competitive with calcium ions. Also, the ability of $\mathrm{WB}$ carbonized at $1000^{\circ} \mathrm{C}$, to remove lead ions, was higher than that by WB in the low concentration range. The amount of magnesium ions eluted from carbonized WB per unit mass was highest for WB carbonized at $800^{\circ} \mathrm{C}$, and was approximately 8 times the amount eluted from WB. Furthermore, the total viable bacteria count after $36 \mathrm{~h}$ of WB treatment at $15-35^{\circ} \mathrm{C}$ was 7380 or more. However, the total viable bacteria count after $48 \mathrm{~h}$ for carbonized WB was 20 - 280, suggesting the possible usage for treatment of drinking water. These results suggest that carbonized WB can be a new adsorbent, have the mineral release ability -- i.e. an adsorbent which removes lead ions which are harmful to people, and releases calcium ions and magnesium ions which are beneficial to people.
\end{abstract}

KEYWORDS: water treatment, adsorption, carbonization, vegetable biomass 


\section{INTRODUCTION}

Developed countries have water treatment plants that can remove heavy metal ions. For developing countries, however, it is necessary to develop simple water treatment technologies due to lack of water treatment plants. It has been previously reported that lead ions can be removed by coffee grounds as vegetable biomass (Tokimoto et al., 2005); wheat bran (WB) adsorbs $\mathrm{Cr}, \mathrm{Cu}$, $\mathrm{Pb}, \mathrm{Ni}, \mathrm{Cd}$ and other metals (Farajzadeh and Monji, 2004); and lignin extracted from WB adsorbs $\mathrm{Cu}$ and $\mathrm{Zn}$ (Dupont et al, 2005). A model for $\mathrm{Cu}$ adsorption by $\mathrm{WB}$ has also been reported (Singh et al., 2004). WB is primarily used as livestock feed, and at present, other ways of using it, are seldom studied. Also, incineration of vegetable biomass, which is no longer needed, increases carbon dioxide in the atmosphere. It has become necessary to develop new non-feed applications in order to effectively use WB as a vegetable biomass. Recycling technology of the vegetable biomass has been reported. (Hirata et al., 2002; Kawasaki et al., 2005; Bun-ei et al., 2005; Nakanishi et al., 2002).

On the other hand, polyvinyl chloride (PVC) is widely used as a material for water pipes. Other types of water pipe include polyethylene pipe and lead pipe. Lead pipe has been frequently used even in modern water systems because it is flexible, easy to work with, and does not rust. However, society has reexamined the toxicity of lead: it accumulates in the human body, and the effects of chronic poisoning include mental retardation in unborn children and infants. In Japan, approximately $20 \%$ of all water pipes (around 8.5 million or more households) have lead pipes. However, there has been little progress in replacing lead pipes, and it has been predicted that many houses cannot meet water quality standards. The World Health Organization (WHO) has set a water quality standard for lead of at most $0.01 \mathrm{mg} / \mathrm{L}$. Therefore, it has become necessary to develop the technology for removing lead ions without replacing lead pipes.

Natural water contains 50 - $300 \mathrm{mg} / \mathrm{L}$ of minerals such as cations, anions and released matter, but since the cations are bivalent cations like lead, they are thought to be removed simultaneously with lead. Furthermore, adsorption of calcium ions by activated carbon (Xiao and Thomas, 2004; Lim et al., 2002), and competitive adsorption of various cations by zeolite and clay minerals (Panayotova, 2000) have been reported. Therefore, previous water treatment technologies simultaneously remove metal ions, which are beneficial to people, and metal ions which are harmful to people.

In this research, an adsorbent was fabricated from vegetable biomass, to be used as a simple water treatment technology for developing countries, and for water purifiers in Japan. The investigation focused on the ability of the adsorbent to remove harmful lead ions, and release calcium and magnesium ions which are beneficial to people.

\section{Materials and Methods}

\section{Materials}


Standards used for lead and calcium were $\mathrm{Pb}\left(\mathrm{NO}_{3}\right)_{2}$ (Wako Pure Chemical Ind., Ltd.) and $\mathrm{CaCl}_{2}$ (HACH Company), respectively. Wheat bran (WB) was used as the adsorbent, and it was carbonized (WB2 to WB10) at temperatures ranging from 200 to $1000^{\circ} \mathrm{C}$. The carbonization method involved adding approximately $10 \mathrm{~g}$ of WB to a porcelain crucible, and carbonizing for $2 \mathrm{~h}$ at the specified temperature in a muffle kiln, with a nitrogen gas atmosphere and a heating speed of $5^{\circ} \mathrm{C} / \mathrm{min}$. The carbonization yield was calculated from the weight of the sample before and after carbonization.

\section{Protein content of WB}

Protein content of WB was calculated using the semi-micro Kjeldahl method (Kjeldahl, 1883). First, $0.02 \mathrm{~g}$ of precisely weighed sample was placed in a decomposition flask. Then, $0.5 \mathrm{~g}$ of a decomposition promoter $\left(\mathrm{K}_{2} \mathrm{SO}_{4}: \mathrm{CuSO}_{4} \cdot 5 \mathrm{H}_{2} \mathrm{O}=10: 1\right), 3 \mathrm{~mL}$ of concentrated sulfuric acid, 1 $\mathrm{mL}$ of $30 \mathrm{w} / \mathrm{v} \%$ hydrogen peroxide solution and $25 \mathrm{~mL}$ of $30 \mathrm{w} / \mathrm{v} \%$ sodium hydroxide solution were added. Steam distillation was then carried out, and $100 \mathrm{~mL}$ of distillate was taken as sample solution. A solution prepared by adding $15 \mathrm{~mL}$ of $4 \mathrm{w} / \mathrm{v} \%$ boric acid solution and a few drops of bromcresol green and methyl red were used as adsorbing solution. The test solution was titrated with $0.025 \mathrm{~mol} / \mathrm{L}$ sulfuric acid solution (Wako Pure Chemical Ind., Ltd.), and a separate blank experiment was performed using distilled water. Protein content was calculated using Eq. (1)

$\mathrm{P}=0.7003 \cdot(\mathrm{a}-\mathrm{b}) \cdot 100 / \mathrm{M} \cdot 6.25 \quad \mathrm{Eq}(1)$

where $\mathrm{P}$ is the protein content $(\%)$, a is the sulfuric acid titer $(\mathrm{mL})$ required in the main experiment, $\mathrm{b}$ is the sulfuric acid titer $(\mathrm{mL})$ required in the blank experiment, $\mathrm{M}$ is the weight of the sample (mg) and 6.25 is the nitrogen coefficient.

\section{Adsorption isotherms of metal ions}

The amounts of metal ions adsorbed were calculated from the initial concentration and the equilibrium concentration using the batch method. To determine the adsorption isotherms of lead ions, $0.01 \mathrm{~g}$ of WB or WB2 - 10 was added to $100 \mathrm{~mL}$ of lead ion solutions of varying concentrations. After shaking for $24 \mathrm{hrs}$ at a speed of approximately $100 \mathrm{rpm}$ and a temperature of 15 or $25^{\circ} \mathrm{C}$, filtration was done with a membrane filter, and the equilibrium concentration of lead ions in the filtrate was measured using a scanning-type HAS-1000 lead measurement unit (made by HACH Company). For the amount of calcium ion adsorbed, $0.01 \mathrm{~g}$ of WB or WB2 - 10 was added to $100 \mathrm{~mL}$ of calcium ion solutions of varying concentrations. After shaking for $24 \mathrm{hrs}$ at a speed of approximately $100 \mathrm{rpm}$ and a temperature of 15 or $25^{\circ} \mathrm{C}$, filtration was done with a membrane filter, and the equilibrium concentration of calcium ions in the filtrate was measured using the DR/4000 (made by HACH Company). The amount of metal ion adsorbed was calculated using Eq. (2) with the values for initial concentration and equilibrium concentration=

$\mathrm{V}=(\mathrm{Co}-\mathrm{C}) \cdot 100 / 1000 / \mathrm{W} \quad$ Eq. (2)

where $\mathrm{V}$ is the amount adsorbed $(\mu \mathrm{g} / \mathrm{g}), \mathrm{Co}$ is the initial concentration $(\mu \mathrm{g} / \mathrm{L}), \mathrm{C}$ is the equilibrium concentration $(\mu \mathrm{g} / \mathrm{L})$ and $\mathrm{W}$ is the weight of the adsorbent $(\mathrm{g})$. 


\section{Magnesium ion elution}

To determine the amount of magnesium ion elution, $0.01 \mathrm{~g}$ of WB or WB2 - 10 was added to $100 \mathrm{~mL}$ of distilled water. After shaking for $24 \mathrm{hrs}$ at a speed of approximately $100 \mathrm{rpm}$ and a temperature of $25^{\circ} \mathrm{C}$, filtration was done with a membrane filter, and the concentrations of calcium and magnesium ions in the filtrate were measured using DR/4000 (made by $\mathrm{HACH}$ Company). The amounts of elution of calcium and magnesium ions per unit mass of absorbent were calculated from the results of magnesium ion concentration.

\section{Measurement of total viable bacteria count}

Approximately $0.01 \mathrm{~g}$ of WB or WB2 - 10 was added to $100 \mathrm{~mL}$ of distilled water, and after shaking for a fixed amount of time, the total viable bacteria count was measured using a SimPlate TPCI (made by GSI Creos). Measurement was done in the temperature range of 15 $35^{\circ} \mathrm{C}$ for $\mathrm{WB}$, and at $25^{\circ} \mathrm{C}$ for $\mathrm{WB} 2-10$.

\section{RESULTS AND DISCUSSION}

\section{Adsorption isotherms of lead and calcium ions onto WB}

Figure 1 shows the adsorption isotherms for lead ions onto $\mathrm{WB}$ at 10 and $25^{\circ} \mathrm{C}$. The results show that the amount of lead ion adsorbed onto WB in a single solution increased as the temperature increased. In general, in the case of physical adsorption, the amount adsorbed increases as the temperature decreases, but the amount of lead ion adsorbed onto WB decreased as the temperature during adsorption decreased. Therefore, chemical factors are also thought to be significantly affecting the adsorption of lead ions in WB. On the other hand, the amount of lead ion adsorbed onto WB in a binary solution exhibits lower values than the amount adsorbed in a single solution, therefore, it is clear that there is competitive adsorption of lead ions and calcium ions. A drop in lead ion adsorption accompanying a rise in calcium ion concentration has been recognized with zeolite and clay minerals, and thus it has been clearly shown that there is competitive adsorption (Panayotova, 2000). The same tendency is also evident in WB, and it was found out that some adsorption sites for calcium ions and lead ions in WB are the same. It is thought that the marked drop in the amount of lead ions adsorbed was caused by the increase in molecular motion at higher adsorption temperatures, and mutual competition between lead ions and calcium ions. 


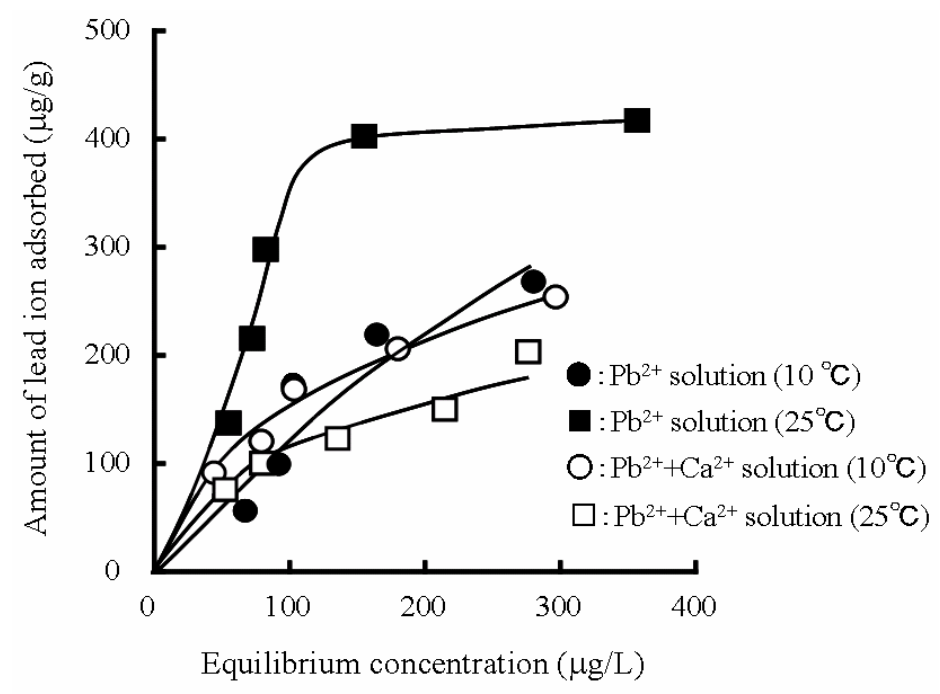

Fig. 1 Amount of lead ion adsorbed onto WB in single and binary solutions

Figure 2 shows the adsorption isotherms of calcium ions onto $\mathrm{WB}$ at 10 and $25^{\circ} \mathrm{C}$. The results show that the amount of calcium ion adsorbed onto $\mathrm{WB}$ in a single solution exhibited higher values as the temperature increased, just like the adsorption behavior of lead ions onto WB. On the other hand, the amount of calcium ion adsorbed onto WB in a binary solution did not depend on temperature, and it was almost the same. In order to adopt experimental conditions close to conditions for practical use, the initial concentrations of lead ions and calcium ions were set to $600 \mu \mathrm{g} / \mathrm{L}$ and $10 \mathrm{mg} / \mathrm{L}$, respectively, in the adsorption experiments with a binary solution. Thus, lead ion adsorption onto WB was greatly affected by calcium ions, but it is thought that calcium ion adsorption onto WB was not greatly affected by lead. In other words, this suggests that when WB is used as an adsorbent for removing lead ions, the calcium ions necessary for people are removed, and the adsorptive capacity for lead ions decreases due to the coexistence of calcium ions.

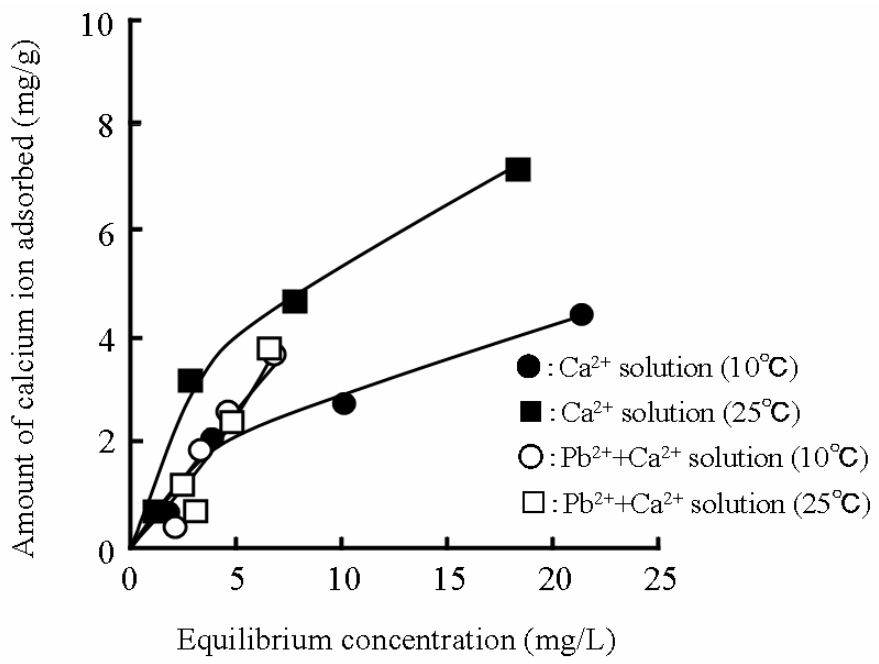

Fig. 2 Amount of calcium ion adsorbed onto WB in single and binary solutions 


\section{Total viable bacteria count in water due to the addition of WB}

After adding WB to drinking water as an adsorbent, the different samples were shaken for fixed times at temperatures ranging from 15 to $35^{\circ} \mathrm{C}$, and the total viable bacteria counts in the solutions were measured. The results are shown in Table 1 . The results show that the total viable bacteria count increased as the temperature during treatment increased. When the treatment temperature is 15 or $25^{\circ} \mathrm{C}$, the total viable bacteria count is 7380 or higher at $36 \mathrm{~h}$ or more. On the other hand, when the treatment temperature is $35^{\circ} \mathrm{C}$, the total viable bacteria count is 7380 or higher at $21 \mathrm{~h}$ or more. WB is a food derivative, and it contains the three macronutrients (protein, fat, and carbohydrates). Thus, it provides an environment where bacteria multiply. The total viable bacteria count also increases with increasing temperature, and thus it is thought that WB is defective from the context of practical application as an adsorbent for water treatment.

Table 1 Viable bacterial counts in water treated with WB at different temperatures

\begin{tabular}{cccc}
\hline \multirow{2}{*}{ Time (h) } & \multicolumn{3}{c}{ Viable bacterial counts } \\
\cline { 2 - 4 } & $15^{\circ} \mathrm{C}$ & $25^{\circ} \mathrm{C}$ & $35^{\circ} \mathrm{C}$ \\
\hline 0 & 0 & 1 & 12 \\
12 & 3 & 3 & 393 \\
15 & 12 & 15 & 623 \\
18 & 17 & 29 & 3149 \\
21 & 140 & 200 & $>7380$ \\
24 & 330 & 640 & $>7380$ \\
36 & $>7380$ & $>7380$ & $>7380$ \\
39 & $>7380$ & $>7380$ & $>7380$ \\
42 & $>7380$ & $>7380$ & $>7380$ \\
\hline
\end{tabular}

\section{Properties of WB and WB2 -10}

Table 2 shows the amounts of carbon and nitrogen in WB and WB2 - 10 (measured by elemental analysis), the apparent protein content measured using the semi-micro Kjeldahl method, and the yield after carbonization. The results show that WB is $42.9 \%$ carbon, and the amount of carbon after carbonization ranges from $43.9 \%$ to $60.5 \%$. WB is converted to carbon material with a particularly high amount of carbon when it is carbonized at a temperature of $400^{\circ} \mathrm{C}$ or higher. The amount of nitrogen and the yield decreased with increasing carbonization temperature. On the other hand, the amount of apparent protein in WB was highest in WB4, and at temperatures beyond $400^{\circ} \mathrm{C}$, it decreased as the carbonization temperature increased. These results on yield and amount of carbon show that carbonization treatment of WB converts it to a material with a higher amount of carbon. Furthermore, protein mass increases with increasing carbonization temperature up to $400^{\circ} \mathrm{C}$, but decreases thereafter. Therefore, it is thought that emissions of carbon dioxide into the atmosphere can be reduced by carbonization treatment of WB. 
Table 2 Nitrogen, carbon and apparent protein content and the yield of carbonized WB

\begin{tabular}{ccccc}
\hline Samples & Carbon (\%) & Nitrogen (\%) & $\begin{array}{c}\text { Apparent } \\
\text { protein }(\%)\end{array}$ & Yield (\%) \\
\hline WB & 42.9 & 6.19 & 19.2 & - \\
WB2 & 43.9 & 7.32 & 19.2 & 92.7 \\
WB4 & 60.5 & 3.65 & 28.7 & 39.5 \\
WB6 & 60.3 & 2.16 & 25.2 & 30.7 \\
WB8 & 56.8 & 1.65 & 18.5 & 25.4 \\
WB10 & 57.3 & 1.60 & 9.5 & 21.4 \\
\hline
\end{tabular}

\section{Adsorption isotherms of lead ions onto WB2 - 10}

Figure 3 shows adsorption isotherms of lead ions onto WB and WB2 - 10. The results show that the amount of lead ion adsorbed onto WB2 and WB4 was almost the same. Also, the amount of lead ion adsorbed onto WB6 and WB8 was lower than in WB at all concentration ranges. Furthermore, the amount of lead ion adsorbed onto WB10 at an equilibrium concentration of $100 \mu \mathrm{g} / \mathrm{L}$ or less was higher than in WB, and the shape of the adsorption isotherm was the same as that for adsorption in activated carbon. This is thought to be because WB10 has a porous structure like activated carbon. These results suggest that the mechanism of lead ion adsorption onto WB and WB2 - 6 is adsorption by the protein in WB, and the mechanism of adsorption onto WB8 and WB10 is adsorption by the pores formed due to carbonization.

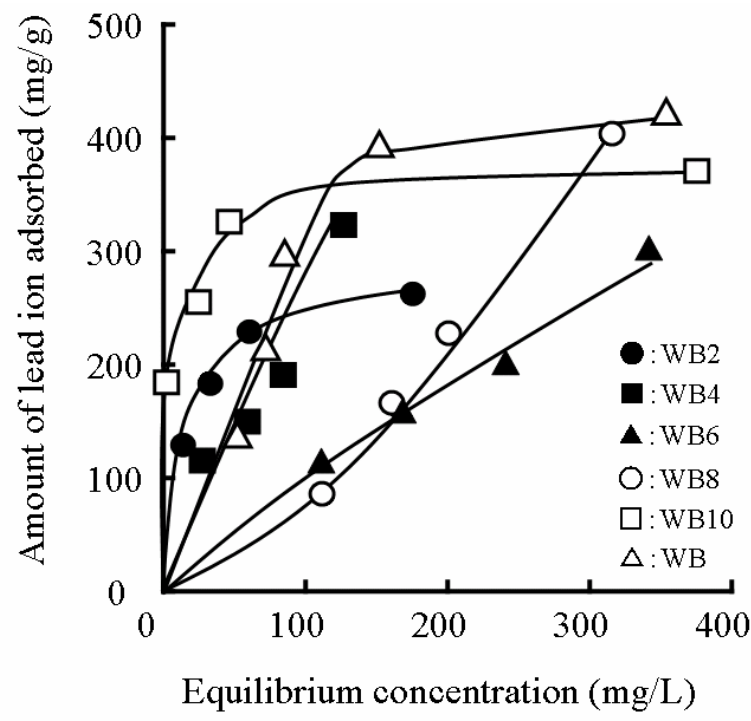

Fig. 3 Amount of lead ion adsorbed onto carbonized WB

\section{Amounts of calcium ions and magnesium ions eluted from WB}

There have been no reports regarding the elution of calcium ions and magnesium ions from WB. However, calcium ions and magnesium ions are crucial ions for preventing 
osteoporosis in people (An et al., 2005). Figure 4 shows the amounts of calcium ion and magnesium ion eluted from WB and WB2 - 10. From these results, it is evident that the amount of calcium ion elution is less than the amount of magnesium ion eluted. Also, the amounts of calcium ion and magnesium ion eluted from WB into distilled water were $0.9 \mathrm{mg} / \mathrm{g}$ and $5.3 \mathrm{mg} / \mathrm{g}$, respectively. On the other hand, since the boiling points of calcium and magnesium are $1494^{\circ} \mathrm{C}$ and $1107^{\circ} \mathrm{C}$, respectively, the amount of calcium and magnesium contained in WB presumably increase due to carbonization. Therefore, it is thought that the amounts of calcium ions and magnesium ions eluted from WB6-WB10 are higher than from WB, and there was an increase particularly in the amount of magnesium ions eluted. A decrease in the amount of magnesium eluted was evident with WB10, and this is likely because the boiling point of magnesium is $1107^{\circ} \mathrm{C}$, and some of the magnesium in WB vaporized during carbonization. When the magnesium content per unit mass of WB8 is calculated from the amount of magnesium ions eluted from WB and the carbonization yield of $25.4 \%$, the result is $19.7 \mathrm{mg} / \mathrm{g}$. However, the amount of magnesium ions eluted from WB8 exhibited the highest value of $37.3 \mathrm{mg} / \mathrm{g}$, and thus, it is probable that carbonization changed the structure to one which facilitates magnesium ion elution. The amount of magnesium ions eluted from WB2 was about the same as from WB, and there was almost no effect due to carbonization. On the other hand, the amount of magnesium ions eluted from WB4 decreased compared to WB, and it can be predicted that the structure of WB4 inhibits elution of magnesium. This suggests that the magnesium in WB4 is present in a stable form in the structure produced by carbonization, and this makes it impossible for magnesium to elute.

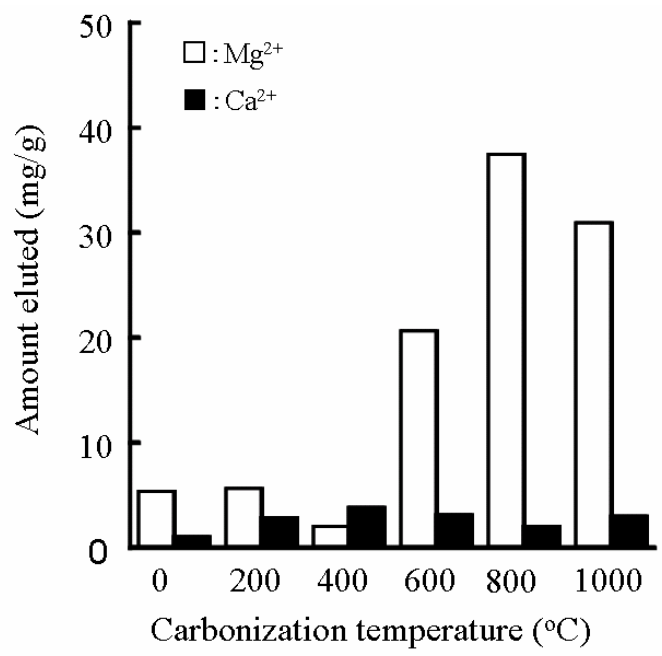

Fig. 4 Amount of magnesium or calcium ions eluted from carbonized WB at different temperatures

\section{Total viable bacteria count due to WB2 - WB10}

Bacterial regrowth in drinking water distribution systems is a source of concern, since it could result in noncompliance with water quality regulations and taste and odor problems may be associated. To actually use food-derived adsorbents such as WB, it is crucial to evaluate total viable bacteria counts in order to prevent impairment of human health (Prevost et al., 1998). Table 3 shows the results of adding WB2 - WB10 to water as an absorbent, shaking for fixed 
times at $25^{\circ} \mathrm{C}$, and measuring total viable bacteria count in the solutions. The results show that, even after $48 \mathrm{~h}$, the total viable bacteria count was 20 - 280. The multiplication speed of total viable bacteria was lower than with $\mathrm{WB}$, suggesting for its possible use as an adsorbent for water treatment. The total viable bacteria counts due to adding WB2 and WB4 to water were greater than for WB6, WB8 and WB10. This is probably because WB2 and WB4 have a higher nutrient content than WB6 and WB10.

Table 3 Viable bacterial counts in water treated with carbonized WB

\begin{tabular}{cccccc}
\hline Time $(\mathrm{h})$ & WB2 & WB4 & WB6 & WB8 & WB10 \\
\hline 6 & 0 & 0 & 0 & 0 & 0 \\
15 & 20 & 0 & 20 & 20 & 0 \\
24 & 0 & 0 & 20 & 0 & 0 \\
48 & 280 & 280 & 80 & 140 & 20 \\
\hline
\end{tabular}

\section{CONCLUSION}

The addition of calcium ions caused no apparent change in the amount of lead ions removed by WB when temperature is low, but the amount removed decreased as the adsorption temperature increased. Also, the ability of $\mathrm{WB}$ carbonized at $1000^{\circ} \mathrm{C}$, to remove lead ion, was greater than that of WB in the low concentration range.

The amount of magnesium ions eluted from carbonized WB per unit mass was higher than from WB, and the amount of calcium ions eluted somehow increased. Furthermore, the results on total viable bacteria counts show that the total viable bacteria count is low, even after $48 \mathrm{~h}$, when carbonized WB is used as an adsorbent for water treatment, and thus, it can be used for drinking water. These results suggest that carbonized WB removes harmful lead ions, while releasing calcium ions and magnesium ions which are beneficial to people -- i.e. it can be a new adsorbent, have the mineral release ability.

\section{RERERENCES}

An, L., Zhang, C., Liu, G. and Li, J. (2005) Effect of drinking water contained low level calcium and high level magnesium on bone metabolism of ovariectomized rats Huanjing. $Y u$ Jiankang Zazhi, Vol.22, No.5, 343-345.

Bun-ei, R., Kawasaki, N., Nakamura, T., Ogata, F. and Tanada, S. (2005) Relationship between surface polarity and moisture control onto carbonaceous materials produced from bean curd lees. J. Oleo Sci., Vol.55, No.1, 23-29.

Dupont, L., Bouanda, J., Dumonceau, J. and Aplincourt, M. (2005) Biosorption of $\mathrm{Cu}(\mathrm{II})$ and $\mathrm{Zn}$ ( II ) onto a lignocellulosic substrate extracted from wheat bran. Fr. Environ. Chem. Lett., Vol.2, No.4, 165-168. 
Farajzadeh, M. A. and Monji, A. B. (2004) Adsorption characteristics of wheat bran towards heavy metal cations. Separ. Purif. Technol. Vol.38, No.3, 197-207.

Hirata, M., Kawasaki, N., Nakamura, T., Matsumoto, K., Kabayama, M., Tamura, T. and Tanada S. (2002) Adsorption of dyes onto carbonaceous materials produced from coffee grounds by microwave treatment. J. Colloid Interface Sci., Vol.254, No.1, 17-22.

Kawasaki, N., Kinoshita, H., Oue, T., Nakamura, T. and Tanada, S. (2006) Deodorization of ammonia by coffee grounds. J. Oleo Sci., Vol.55, No.1, 31-35.

Kjeldahl, J. Z. (1883) Neue methode zur bestimmung des stickstoffs in organischen korpern. Anal. Chem., Vol.22, 366-382.

Lim, T., Tay, J. and The, C. (2002) Significance of aqueous cation composition on heavy metal mobility in a nature clay. Wat. Environ. Res., Vol.74, No.4, 346-353.

Nakanishi, A., Tamai, M., Kawasaki, N., Nakamura, T., Araki, M. and Tanada, S. (2002) Characterization of water adsorption onto carbonaceous materials produced from food wastes. J. Colloid Interface Sci., Vol.255, No.1, 59-63.

Panayotova, M. (2000) Kinetics of heavy metal ions removal from wastewater by natural zeolite in the presence of calcium and magnesium ions. J. Environ. Protect. Ecol., Vol.1, No.3, $350-355$.

Prevost, M., Rompre, A., Coallier, J., Servais, P., Laurent, P., Clement, B. and Lafrance, P. (1998) Suspended bacterial biomass and activity in full-scale drinking water distribution systems: impact of water treatment. Water Res., Vol.32, No.5, 1393-1409.

Singh, K. K., Singh, N. L. and Hasan, S. H. (2004) Removal of copper from wastewater by agricultural waste wheat bran. Ind. J. Environ. Potect., Vol.27, No.7, 499-505.

Tokimoto, T., Kawasaki, N., Nakamura, T., Akutagawa, J. and Tanada, S. (2005) Removal of lead ions in drinking water by coffee grounds as vegetable biomass. J. Colloid Interface Sci., Vol.281, No.1, 56-61.

Xiao, B. and Thomas, K. M. (2004) Competitive adsorption of aqueous metal ions on an oxidized nanoporous activated carbon. Langmuir, Vol.20, No.11, 4566-4578. 